\title{
Effects of Refrigeration Storage on the Ascorbic Acid (VIT C) Content of Pear- Amla Based Ready-To-Serve (RTS) Beverages)
}

\author{
Sanjay Kumar ${ }^{1}$, Chitra $^{2}$, DeepikaKohli ${ }^{3}$, Ritesh Mishra ${ }^{4}$, Shuchi Upadhyay ${ }^{5}$ \\ 1,2,3,5 Department of Food Technology, UIT, Uttaranchal University, Dehradun \\ ${ }^{4}$ Department of Agricultural science and Engineering, IFTM University, Moradabad
}

\begin{abstract}
High ascorbic acid Pear (Pyruscommunis) and Amla (Emblicaphyllanthusor Emblicaofficinalis) based RTS were prepared at various combinations (80:20,75:25 and 50:50) and various physico-chemical properties like $\mathrm{pH}$, TSS, titrable acidity, reducing sugar and Ascorbic acid content were evaluated during storage period of 0 , 7, 15 days. The study revealed that RTS-3 prepared with 50\% Pear and 50\% Amla juice scored maximum amount of ascorbic acid content $(322.85 \mathrm{mg} / 100 \mathrm{~g})$.In this study increasing trend was observed in case of $\mathrm{pH}$, TSS, Titrable acidity during the refrigeration storage of Pear- Amla based ready-to-serve (RTS) beverages over a period of 15 days but ascorbic acid content was decreased.
\end{abstract}

Keywords: RTS, Pear, Amla, Ascorbic acid

\section{INTRODUCTION}

Now these days Ready-To-Serve (RTS) beverages have been popular throughout the country due to higher content of nutritional, medicinal and calorific properties over the non- fruit based beverages (Tiwari and Deen, 2015). Fruit based RTS beverages are rich source of essential minerals and vitamins. RTS also have good taste and flavor. Fruit based Ready-To-Serve (RTS) beverages are commonly acceptable beverages throughout the country.

Pear (Pyruscommunis) belongs to family Rosaceae. It is seasonal fruit and rich in phelonics. The phenolic compounds are useful for preventing some diseases like cardiovascular and inflammatory diseases and carotenoids avoid age-related macular degeneration (Scalbert and Williamson, 2000; Daly, et al., 2010).Vitamin $C$ is useful for reducing the risk of several cardiovascular, neurodegenerative diseases (Harrison and May, 2009). Pear is a good source of vitamins, minerals, pectin, dietary fibers and phytochemicals. Pears juice is beneficial for the people those are suffering from acidity and diabetics. Tulsi (Ocimumtenuiflorum, Ocimum sanctum), is an aromatic plant in the family Lamiaceae which is native to the Indian subcontinent and widespread as a cultivated plant throughout the Southeast Asian tropics. (Warrier, P.K., 1995). The tulsi leave extracts with methanol, water, and acetone were used to monitor the anti-bacterial property against clinically isolated MDR bacterial strains (Staples, George; Michael S. Kristiansen, 1999). Juice or infusions of tulsi are useful for the treatment of bronchitis, digestive problems, arthritis, hypertension, heart attack, cancer, viral hepatitis, diabetes etc. It is an excellent rejuvenator, which has been known to reduce anxiety, stress and relaxes the mind. Tulsi plant is valued for its anti-toxic (Sharma et al., 2002); antitussive (Nadig and Laxmi, 2005); hypoglycaemic and hypolipidemic properties thereby making it useful for diabetic patients (Rai et al., 1997). The aqueous extract of Tusli shows antimicrobial properties (Geeta et al., 2001; Singh et al., 2005) and also helps to reduce blood sugar in normal, glucose fed hyperglycemic and streptozotocin, induced diabetic rats (Chattopadhay, 1993; Pandey and Madhuri, 2010). Amla

(Emblicaphyllanthusor Emblicaofficinalis) is one of the most medicinal herbs and widely used in ayurvedic medicines. The amla act as antioxidants (Chopra et al., 1956); and protect against oxidative stress in ischemic reperfusion injury (Raja, k. et al., 2004). Amla is one of the richest sources of vitamin- C, amino acids and minerals (Srivasuki, K.P., 2012). Due to high vitamin $\mathrm{C}$ content this is liable for keeping body cells, increases red blood cells and promotes good health (Kapoor, L.D., 1990). It also contains several chemicals like tannins, alkaloids and phenols (Zhang, L.Z.et al., 2003). The fresh juice of amla acts as diuretic and helpful in burning urinary infection and when mixed with other ingredients are used to cure fits and insanity (Jayaweera, D.M.A., 1980).

On the basis of all these fruits health benefits and nutritional values the present study is focused on the preparation and storage stability of Fruit based Ready- To- Serve (RTS) beverages. 


\section{MATERIALS AND METHODS}

\subsection{Raw materials}

Fresh and mature fruits were procured from local market of Premnagar, Dehradun, Uttarakhand and were used for the preparation of RTS. All the chemicals used to evaluate the quality parameter were analytical grade.

\subsection{Preparation of Juices}

\subsubsection{Preparation of Pear juice}

Fresh and mature Pear fruit were washed in fresh water to remove the surface impurities. After washing peeling was done by knife and juice were extracted mechanically by using Havells Juicer. After extraction juice is stored at $4 \pm 1^{\circ} \mathrm{C}$ until use.

\subsubsection{Preparation of Amla juice}

Fresh and mature Amal fruit were washed in fresh water and any surface defect is removed by knife. After washing remove the stone of Amla and juice were extracted mechanically and stored at $4 \pm$ $1{ }^{\circ} \mathrm{C}$ until use.

\subsubsection{Preparation of Tulsi Extract}

Fresh Tulsi leaves were washed properly in fresh water and blended in a laboratory blender. Then the extract was filtered with water through muslin cloth to obtain the Tulsi Extract.

\subsubsection{Preparation of Pear - Amla Based RTS}

Pear -Amla based RTS were prepared by mixing the previously prepared juices by using various blend combination such as 80:20, 75:25 and 50:50 with $5 \mathrm{ml}$ of Tulsi Extract and $5 \mathrm{ml}$ of sugar solution. All the combination were prepared $200 \mathrm{ml}$ and filled in previously sterilized glass bottels.

\subsection{Physicochemical analysis of raw Juices and prepared RTS's}

Raw juices and Prepared RTS with different combination of Pear and Amla Juice (80:20, 75:25 and 50:50) i.e. RTS-1 [Pear:Amla Juice(80:20)], RTS-2[Pear:AmlaJuice $(75: 25)]$, RTS3[Pear:AmlaJuice (50:50)] were analyzed for various physico-chemical properties like $\mathrm{pH}$, TSS, titrable acidity, reducing sugar and Ascorbic acid content. $\mathrm{pH}$ of all juices were analyzed by handy $\mathrm{pH}$ meter, TSS were measured in ${ }^{\circ}$ Brix by handy refractometer (ERMA), titrable acidity was measured by the standard method of Rangana, 2010 ,by using N/10 $\mathrm{NaOH}$ and expressed in terms of percentage of citric acid. Reducing sugars were determined by the method of Lane and Eynon, 1923. Ascorbic acid in raw as well as RTS were measured by standard method of Sawhney, S.K. and Singh, R., 2015.

\section{RESULTS AND DISCUSSION}

3.1Physicochemical analysis of Pear (Pyruscommunis) and Amla (Emblicaphyllanthus or Emblicaofficinalis) Juice

$\mathrm{pH}$, of Pear and Amla juice were reported to $4.6 \&$ 3.0, TSS of Pear and Amla juice were reported to $12.1 \& 8.1$, Titrable Acidity (\% citric acid) of Pear and Amla juice were reported to $0.576 \& 2.608, \%$ Reducing Sugar of Pear and Amla juice were reported to $6.9 \%$ \& $8.33 \%$, Ascorbic acid (Vit C) $\mathrm{mg} / 100 \mathrm{ml}$ of Pear and Amla juice were reported to 1.71 and $821.1 \mathrm{mg} / 100 \mathrm{ml}$, Moisture Content of Pear and Amla juice were reported to $86.45 \& 90.43$ and Ash content of Pear and Amla juice were reported to $1.49 \& 2.42$ respectively as Shown in Table 1 .

pH, TSS, Titrable Acidity, \% Reducing Sugar, Ascorbic acid (Vit C) mg/100 ml, Moisture Content and Ash content of Pear Juice (Pyruscommunis) are similar to some extent as reported by Mohammed I. Talib et. al., 2016.

$\mathrm{pH}$, TSS, Titrable Acidity, \% Reducing Sugar, Ascorbic acid (Vit C) mg/100 ml, Moisture Content and Ash content of Amal (Phyllanthusemblica) Juice are similar to some extent as reported by Karpagavalli, B. et. al., 2014. Ascorbic acid (Vit C) $\mathrm{mg} / 100 \mathrm{ml}$ of Amla is similar to some extent as reported by Sasi Kumar et al., 2013.

Physicochemical changes during refrigeration storage of RTS are presented in Table 2. which shows that $\mathrm{pH}$ increased gradually after 7,15 days in case of RTS- 1 from 2.9 to 3.4 , in case of RTS-2 from 2.8 to 3.2 and in case of RTS-3 from 2.5 to 3.0 as shown in Figure 1. The similar result in increased $\mathrm{pH}$ during storage was found by Kayshar, M.S. et al., 2014.

Total soluble solids increased gradually after 7 to15 days in case of RTS-1 from 11.3 to $11.9^{\circ}$ brix, in case of RTS-2 from 12.0 to $12.8^{\circ}$ brix and in case of RTS-3 from 12.4 to $13.2^{\circ}$ brix as shown in Figure 2.The changes in TSS may be due to the conversion of polysaccharides into sugars. Similar trend of increasing in TSS during storage was reported in Aloe- vera based Ready to Serve Soft drink (Mohammed I. Talib et al., 2016) and in bael and Aloe- vera blended RTS (Tiwari, D. K. and Deen, B., 2015). The increasing trends in TSS of RTS may be possible due to the conversion of polysaccharides into sugars.

The titrable acidity of RTS also increased gradually during refrigeration storage. Titrable acidity increased gradually after 7 to 15 days in case of RTS- 1 from 0.59 to $0.64 \%$ citric acid, in case of RTS-2 from 0.48 to $0.72 \%$ citric acid and in case of RTS-3 from 0.84 to $1.26 \%$ citric acid as shown in Figure 3 . The changes in titrable acidity may be due to the degradation of pectic substances could be the reason to increase the acidity of processed fruit products (Conn and Stumf, 1976). 
The reducing sugar increased continuously during refrigeration storage period of 7 to 15 days in case of RTS- 1 from 14.71 to $16.0 \%$, in case of RTS2 from 12.1 to $14.0 \%$ and in case of RTS-3 from 13.15 to $15.30 \%$ as shown in Figure 4. This increasing trend may be due to due to inversion of non-reducing sugars into reducing sugars. This result in present study, similar to Nidhi et al. 2007.

Ascorbic acid (Vit C) content was decreased continuously from the first day to the last day of refrigeration storage of 7 to 15 days in case of RTS-1 from 154.85 to $88.57 \mathrm{mg} / 100 \mathrm{~g}$, in case of RTS-2 from 231.43 to $116.0 \mathrm{mg} / 100 \mathrm{~g}$ and in case of RTS-3 from 423.71 to $322.85 \mathrm{mg} / 100 \mathrm{~g}$ as shown in Figure 5. The oxidation of ascorbic acid into dehydro ascorbic acid may be the reason in decreasing trend in Ascorbic acid (Vit C) content. The similar trend of decreasing Ascorbic acid (Vit C) content was determined by Mandal, P., 2003 in fruit based beverages.

\section{CONCLUSION}

In this study a similar trends of decreasing in Ascorbic acid has been found in case of RTS-1, RTS2 , and RTS-3. The study revealed that RTS-3 prepared with 50\% Pear and 50\% Amla juice scored maximum amount of ascorbic acid content (322.85 $\mathrm{mg} / 100 \mathrm{~g}$ ).In this study increasing trend was observed in case of $\mathrm{pH}$, TSS, Titrable acidity during the refrigeration storage of Pear- Amla based ready-toserve (RTS) beverages over a period of 15 Days.

\section{ACKNOWLEDGMENTS}

This research was carried out in the department of food technology, Uttaranchal University, Dehradun we are sincerely thankful to HOD and Principal of UCALS for providing necessary requirements for smooth conducting of the research work.

\section{REFERENCES}

[1] Chattopadhyay, R.R. (1993). Hypoglycemic effect of Ocimum sanctum leaf extract in normal and streptozotocin diabetic rats. Indian J. Exp. Biol., 31 (11): 891-893.

[2] Chopra, R.N., Nayer, S.C. and Chopra, I.C. (1956). In: Glossary of Indian Medicinal Plants, CSIR, New Delhi, p.42.

[3] Conn, E. E. and Stumf, P. K. (1976).Outlines of Biochemistry, Wiley Eastern Ltd., New Delhi.

[4] Daly, T., Jiwan, M., O'Brien N. and Aherne, S. (2010). Carotenoid content commonly consumed herbs and assessment of their bio accessibility using an in vitro digestion model. Plant Food Human.Nutrition. 65:164-169.
[5] Geetavasudevan, D. M., Kedlaya, R., Deepa, S. and Ballal, M. (2001).Activity of Ocimum sanctum (the traditional Indian medicinal plant) against the enteric pathogens. Indian J. Med. Sci. 55 (8): 434 438.

[6] Harrison, F.E and May, J.M. (2009).Vitamin $\mathrm{C}$ function in the brain; vital role of the ascorbate transportation SUCT2. Free Radical Biology Medicine. 46:719-73068.

[7] Jayaweera, D.M.A, (1980). Medicinal Plants used in Ceylon part2 National Science Council of Sri Lanka. Colombo.

[8] Kapoor, L.D., 1990. Handbook of Ayurvedic Medicinal Plants.CRC Press, Boca Raton.

[9] Karpagavalli, B., Amutha, S., Padmini, T., Palanisamy, R. and Chandrakumar, K. (2014). Effect of Processing on Retention of Antioxidant Components in Value Added Amla Products. Indian Journal of Science and Technology. 7(5): 672-677.

[10] Kayshar, M. S., Rahman, A., Sultana; M. S., Fatema, K. and Kabir, M. F. (2014).Formulation, Preparation and Storage potentiality Study of Mixed Squashes from Papaya, Banana and Carrot in Bangladesh.IOSR journal of agriculture and veterinary science. 7(2): 47-51.

[11] Lane and Eynon, L. (1923).Determination of reducing sugars by Fehling solution with methylene blue as an indicator. J. Soc. Chem. Ind. Londan. 42: 32-7.

[12] Mandal, P. (2003).Studies on preparation and preservation of blended beverages from pineapple (Ananascomosus L.) and phalsa (Grewiasubinaequalis L.). M.Sc. Thesis, N.D. University of Agriculture and Technology, Faizabad, U.P.

[13] Mohammed I. Talib; Rushikesh R. Wayal ; Vishal R. Parate. (2016). Development of Aloe- vera based Ready to Serve Soft drink. International Journal of Engineering Research \& Technology.228-233.

[14] Nadig, P., Laxmi, S. (2005). Study of antitussive activity of OcimumSanctumLinn in guinea pig.Ind.J.Physiol.Pharmcol. 49(2):243-245.

[15] Nidhi, Gehlot, R., Singh, R., Siddiqui, S. and Rana, M. K. (2007). Changes in chemical composition of bael-guava blend ready-to-serve beverage and squash during storage. Haryana J. Hort. Sci. 36(1/2): 4648.

[16] Pandey, G. and Madhuri, S. (2010). Pharmacological activities of Ocimum sanctum (Tulsi): A review. Internat. J. Pharmac. Sci. Rev. \& Res., 5 (1): 61-66. 
[17] Rai, V, Iyer, U, Mani, UU. (1997). Effect of tulsi (ocimum sanctum) leaf powder supplementation on blood sugar levels, serum lipids and tissue lipids in diabetic rats.Plant Foods Human Nutrition. 50 (1):916.

[18] Raja k, S., Banerjee, S, K., Sood, S., Dinda, K.A., Gupta, Y.K. and Maulik, S.K. (2004). Emblicaofficinalis causes myocardial adaptation and protects against oxidative stress in ischemic- reperfusion injury in rats. Phytother. Res. 18: 54-60.

[19] Rangana, S. (2010). Analysis and quality control for fruit and vegetable products, Tata McGraw Hill Education Pvt. Ltd., New Delhi.

[20] Sasi Kumar R., Ramesh, C. Ray, Prodyut Kumar Paul and Suresh, C.P. (2013).Development and Storage Studies of Therapeutic Ready to Serve (RTS) Made from Blend of Aloe vera, Aonla and Ginger Juice. Journal of Food Processing and Technology.4 (6): 1-6.

[21] Sawhney, S.K. and Singh, R. (2015) Estimation of ascorbic acid in lemon juice. Introductory practical Biochemistry.Narosa Publishing House, New Delhi, pp104-105.
[22] Scalbert A. and Williamson G. (2000).Dietary intake and bioavailability of polyphenols. J. Nutri. 130:2073S- 2085S.

[23] Sharma MK, Kumar A, (2002). Ocimum Sanctum aqueous leaf extract provides protection against mercury induced toxicity in Swiss albino mice. Ind.J.exp.Biol.40 (9):1079-82.

[24] Singh, S. Malhotra, M. and Majumdar, D.K. (2005). Antibacterial activity of Ocimum sanctum L. fixed oil. Indian J Exp. Biol., 43 (9): 835-837.

[25] Srivasuki, K.P., (2012). Nutritional and Healthcare Benefits of Amla. Journal of Pharmacognosy, 3(2): 141-51.

[26] Staples, George; Michael S. Kristiansen, (1999).Ethenic Culinary Herbs.University of Hawali Press. 73.

[27] Tiwari, V.D.K., and Deen, B., (2015). Prepration and storage of blended ready-toserve beverage from bael and aloe.The bioscan. 10(1): 113-116.

[28] Warrier, P.K. (1995).Indian Medicinal Plants.Orient Longman. 168.

[29] Zhang, L.Z., Zhao, W.H., Gua, Y.J., Tu, G.Z., Lin, S., Xin, L.G. (2003).Studies on chemical constituents in fruits of Tibetan medicine Phyllanthusemblica. Zhongguo Zhong Yao ZaZhi. 28(10), 940-943

Table 1.Physicochemical analysis of Pear (Pyruscommunis) and Amla(Emblicaphyllanthus or Emblicaofficinalis.)Juice

\begin{tabular}{|c|l|c|c|}
\hline S. No. & \multicolumn{1}{|c|}{ Parameters } & Pear & Amla \\
\hline 1. & pH & 4.6 & 3.0 \\
\hline 2. & TSS $\left({ }^{\circ}\right.$ Brix) & 12.1 & 8.1 \\
\hline 3. & Titrable Acidity (\% citric acid) & 0.576 & 2.608 \\
\hline 4. & Reducing Sugar (\%) & 6.9 & 8.33 \\
\hline 5. & Ascorbic acid (Vit C) $\mathbf{~} \mathbf{m g} / \mathbf{1 0 0} \mathbf{~ m l}$ & 1.71 & 812.1 \\
\hline 6. & Moisture Content & 86.45 & 90.43 \\
\hline 7. & Ash content & 1.49 & 2.42 \\
\hline
\end{tabular}

Table 2. Effect of refrigeration storage on physicochemical parameters of Pear-Amla based ready-to-serve (RTS) beverages

\begin{tabular}{|c|c|c|c|c|c|c|}
\hline $\begin{array}{c}\text { RTS } \\
\text { (Pear: Amla Juice) }\end{array}$ & $\begin{array}{c}\text { Refrigeration } \\
\text { Storage Period } \\
\text { (Days) }\end{array}$ & $\mathbf{p H}$ & $\begin{array}{c}\text { TSS } \\
\left({ }^{\circ} \text { Brix) }\right.\end{array}$ & $\begin{array}{c}\text { Titrable } \\
\text { Acidity }(\% \\
\text { citric acid) }\end{array}$ & $\begin{array}{c}\text { Reducing } \\
\text { Sugar }(\%)\end{array}$ & $\begin{array}{c}\text { Ascorbic acid } \\
\text { (Vit C) } \\
\text { mg/100 ml }\end{array}$ \\
\hline \multirow{3}{*}{ RTS-1 (80:20) } & $\mathbf{0}$ & 2.9 & $\mathbf{1 1 . 3}$ & $\mathbf{0 . 5 9}$ & $\mathbf{1 4 . 7 1}$ & $\mathbf{1 5 4 . 8 5}$ \\
\cline { 2 - 7 } & $\mathbf{7}$ & $\mathbf{3 . 3}$ & $\mathbf{1 1 . 4}$ & $\mathbf{0 . 6 0}$ & $\mathbf{1 5 . 2}$ & $\mathbf{1 3 4 . 0 0}$ \\
\cline { 2 - 7 } & $\mathbf{1 5}$ & $\mathbf{3 . 4}$ & $\mathbf{1 1 . 9}$ & $\mathbf{0 . 6 4}$ & $\mathbf{1 6 . 0}$ & $\mathbf{8 8 . 5 7}$ \\
\hline \multirow{3}{*}{ RTS-2 (75:25) } & $\mathbf{0}$ & 2.8 & $\mathbf{1 2 . 0}$ & $\mathbf{0 . 4 8}$ & $\mathbf{1 2 . 1}$ & $\mathbf{2 3 1 . 4 3}$ \\
\cline { 2 - 7 } & $\mathbf{7}$ & $\mathbf{3 . 2}$ & $\mathbf{1 2 . 5}$ & $\mathbf{0 . 5 9}$ & $\mathbf{1 4 . 8 0}$ & $\mathbf{1 6 5 . 7 1}$ \\
\cline { 2 - 7 } & $\mathbf{1 5}$ & $\mathbf{3 . 2}$ & $\mathbf{1 2 . 8}$ & $\mathbf{0 . 7 2}$ & $\mathbf{1 5 . 3 0}$ & $\mathbf{1 1 6}$ \\
\hline & $\mathbf{0}$ & 2.5 & $\mathbf{1 2 . 4}$ & $\mathbf{0 . 8 4}$ & $\mathbf{1 3 . 1 5}$ & $\mathbf{4 2 3 . 7 1}$ \\
\cline { 2 - 7 } RTS-3 (50:50) & $\mathbf{7}$ & $\mathbf{2 . 9}$ & $\mathbf{1 2 . 9}$ & $\mathbf{1 . 1 0}$ & $\mathbf{1 4 . 8 0}$ & $\mathbf{3 5 7 . 1 4}$ \\
\cline { 2 - 7 } & $\mathbf{1 5}$ & $\mathbf{3 . 0}$ & $\mathbf{1 3 . 2}$ & $\mathbf{1 . 2 6}$ & $\mathbf{1 5 . 3 0}$ & $\mathbf{3 2 2 . 8 5}$ \\
\hline
\end{tabular}


Figure1. Effect of Refrigeration storage period on $\mathrm{pH}$

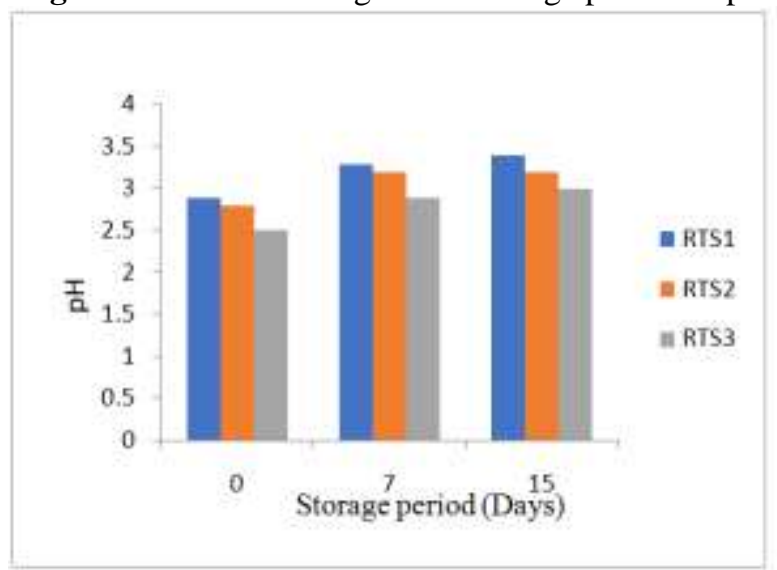

Figure 2. Effect of Refrigeration storage period on TSS

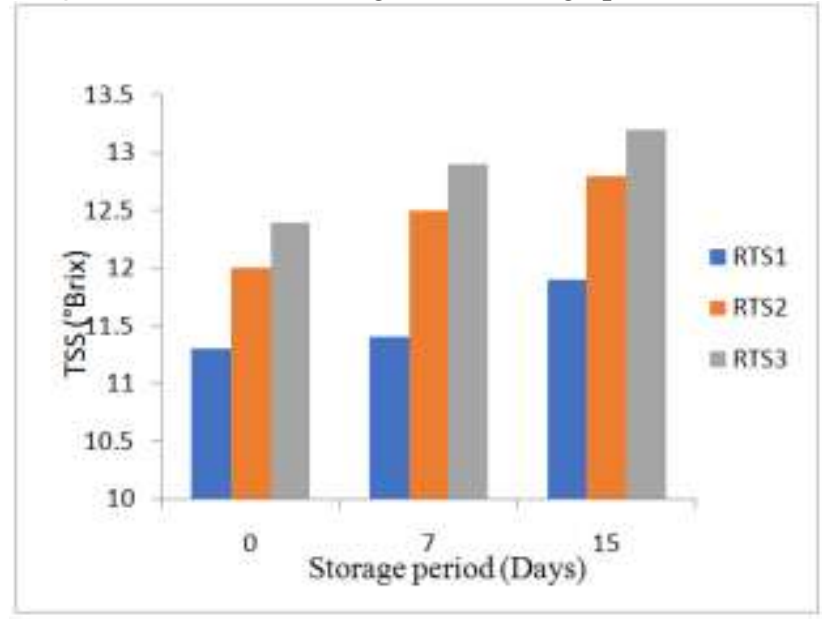

Figure 3. Effect of Refrigeration storage period on Titrable acidity

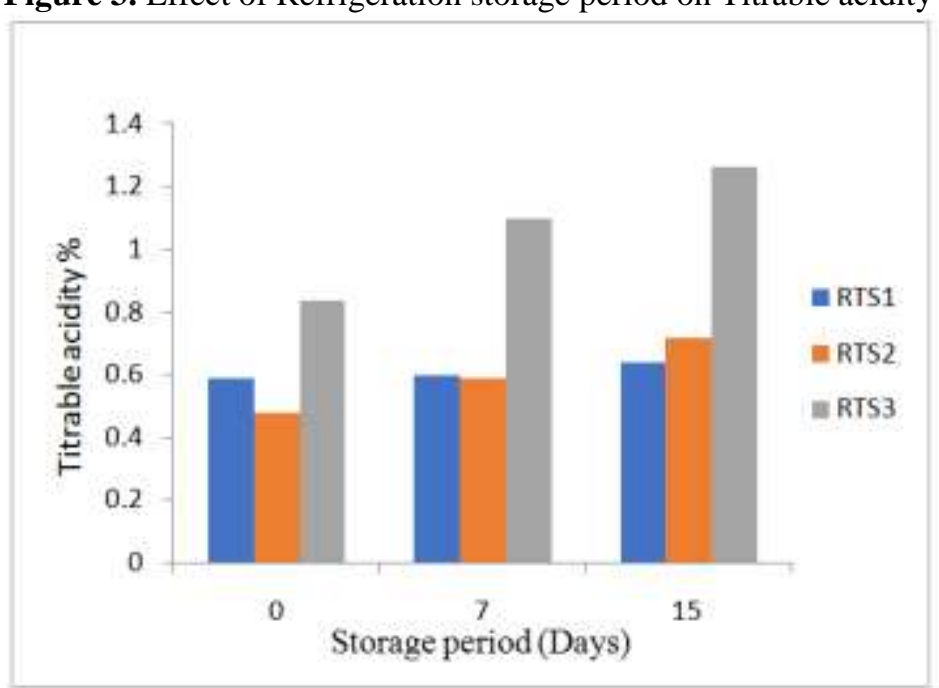


Figure 4. Effect of Refrigeration storage period on Reducing Sugar

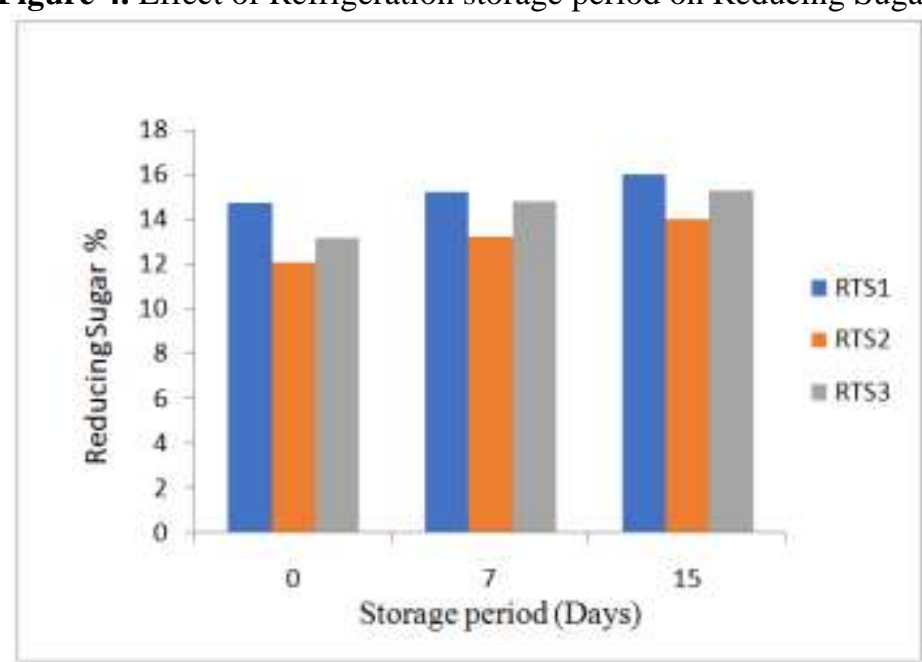

Figure 5. Effect of Refrigeration storage period on Ascorbic acid (Vit. C)

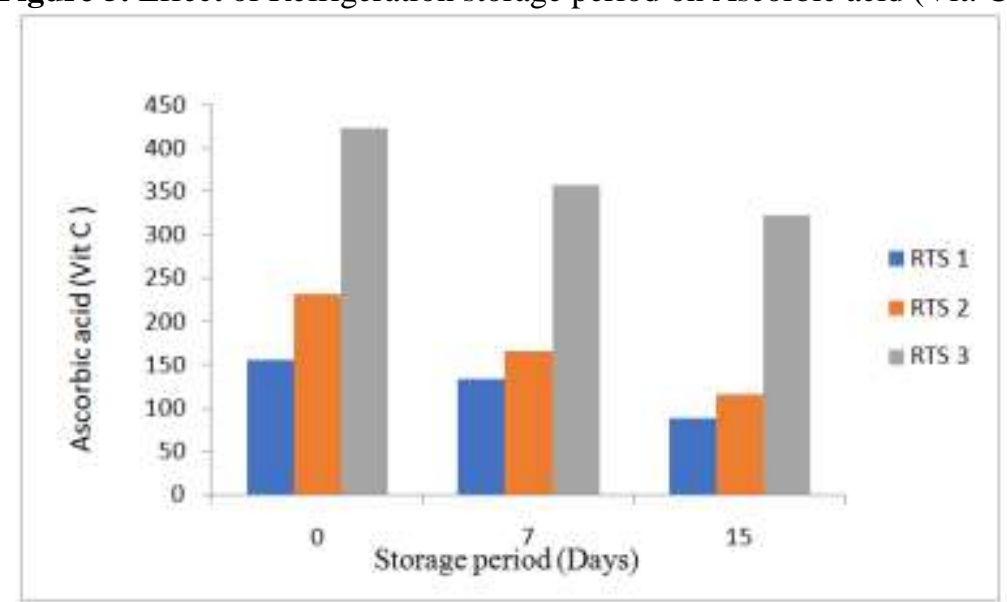

International Journal of Engineering Research and Applications (IJERA) is UGC approved Journal with S1. No. 4525, Journal no. 47088.

Sanjay Kumar " Effects of Refrigeration Storage on the Ascorbic Acid (VIT C) Content of Pear- Amla Based Ready-To-Serve (RTS) Beverages)." International Journal of Engineering Research and Applications (IJERA) 7.7 (2017): 24-29 